\title{
EVALUASI PEMBERIAN PAKAN DENGAN JUMLAH MULTINUTRIENT BLOCK YANG BERBEDA SEBAGAI SUPLEMEN TERHADAP PERFORMANS KAMBING KACANG
}

\author{
EVALUATION OF FEEDING WITH DIFFERENT AMOUNT OF MULTINUTRIENT \\ BLOCK AS A SUPPLEMENT ON KACANG GOAT PERFORMANCES
}

\author{
Dearestantrianto Hadits Fardana, Baginda Iskandar Moeda Tampoebolon, Eko \\ Pangestu, Widiyanto dan Retno Iswarin Pujaningsih \\ Fakultas Peternakan dan Pertanian UNDIP \\ Email : dhfardana.aris@gmail.com \\ Diterima: 17 Juni 2019, Direvisi: 8 Juli 2019, Disetujui: 15 Juli 2015
}

\begin{abstract}
ABSTRAK
Pemberian multinutrien blok sebagai pakan pelengkap bertujuan untuk mengkatalisis pemanfaatan yang lebih efisien dari pakan ternak berkualitas rendah. Penelitian ini bertujuan untuk mendapatkan performans kambing Kacang yang baik melalui pemberian jumlah multinutrien blok (MNB) yang tepat. Metode eksperimental menggunakan 12 ekor Kambing Kacang jantan umur 7 bulan yang dibagi menjadi 3 kelompok berdasarkan berat badannya yaitu, $\mathrm{K} 1(18,75 \pm 1,25 \mathrm{~kg}), \mathrm{K} 2$ $(16,20 \pm 1,20 \mathrm{~kg})$ dan $\mathrm{K} 3(14,20 \pm 1,20 \mathrm{~kg})$. Hijauan jagung dan konsentrat sebagai pakan basal dengan komposisi 20:80. Konsentrat disusun dari bahan baku pakan berupa dedak padi, pollard, kulit kopi, molases. Bahan baku penyusun multinutrien blok terdiri atas hijauan jagung, urea, cangkang kerang darah, cangkang telur, molasses, bentonite dan garam. Rancangan acak kelompok (RAK) dengan 4 perlakuan (T0: Hijauan+Konsentrat, T1: T0+5g MNB, T2: T0+10g MNB, T3: T0+15g MNB) dan 3 ulangan digunakan pada penelitian ini. Parameter yang diamati meliputi pertambahan bobot badan harian $(\mathrm{PBBH})$, konsumsi bahan kering, bahan organik dan total digestible nutrients (TDN). Hasil penelitian menunjukkan pemberian MNB tidak memberikan pengaruh nyata pada konsumsi bahan kering disimpulkan bahwa pemberian MNB tidak memberikan pengaruh yang nyata terhadap konsumsi bahan kering T0 (1066 g), T1 (936 g), T2 $(952 \mathrm{~g}) \mathrm{T} 3(895 \mathrm{~g})$, bahan organik T0 $(967 \mathrm{~g}), \mathrm{T} 1(844 \mathrm{~g}) \mathrm{T} 2(842 \mathrm{~g})$, T3 $(800 \mathrm{~g})$, total digestible nutrients T0 (693 g), T1 $(603 \mathrm{~g})$, T2 $(629 \mathrm{~g})$, T3 $(570 \mathrm{~g})$ dan pertambahan bobot badan T0 (5 kg/ekor), T1 (6,2 kg/ekor), T2 (5,5 kg/ekor), T3 (5,2 kg/ekor) pada Kambing Kacang. Pemberian multinutrien blok sebaiknya diberikan sebagai pakan pelengkap pada ransum berkualitas rendah untuk meningkatkan efisiensi pakan.
\end{abstract}

Kata-kata kunci: kambing Kacang, multinutrien blok, konsentrat, hijauan

\begin{abstract}
Giving multinutrient blocks as a feed supplement aims to catalyze more efficient use of poor quality animal feed. This study aimed to get good performance of Kacang goats through the providing of the right amount of multinutrient blocks (MNB). The experimental method used 12 male goats which were divided into 3 groups based on their body weight, K1 (18,75 $\pm 1,25 \mathrm{~kg}), \mathrm{K} 2$ $(16,20 \pm 1,20 \mathrm{~kg})$ and $K 3(14,20 \pm 1,20 \mathrm{~kg})$. Corn forage and concentrate fed as basal feed with a composition of 20: 80. Concentrates were composed from rice bran, pollard, coffee peel and molasses. The multinutrient blocks materials consisted of corn forage, urea, blood clam shells,
\end{abstract}


eggshells, molasses, bentonite and salt. Randomized block design (RBD) with 4 treatments (T0: Forage + Concentrate, T1: TO + 5g MNB, T2: TO + $10 g$ MNB, T3: TO + 15g MNB) and 3 replications was used in this study. The parameters observed included daily body weight gain, dry matter and organic matter consumption and total digestible nutrients (TDN). From the results of the study it was concluded that MNB's supplementation did not have a significant effect on dry matter T0 (1066 g), T1 (936 g), T2 (952 g) T3 (895 g), and organic matter consumption T0 (967 g), T1 (844 g) T2 (842 g), T3 (800 g), total digestible nutrients T0 (693 g), T1 (603 g), T2 (629 g), T3 (570 g) and body weight gain T0 (5 kg/head), T1 (6,2 kg/head), T2 (5,5 kg/head), T3 (5,2 kg/head) of Kacang goats. It can be suggest that multinutrient blocks should be given as a feed suplement in low quality rations to improve feed efficiency.

Keywords: Kacang goat, multinutrient block, concentrate, forage

\section{PENDAHULUAN}

Ternak kambing dinilai prospektif dikembangkan pada tingkat usaha tani. Hal tersebut didasarkan atas beberapa faktor, antara lain harganya terjangkau oleh petani peternak, waktu dewasanya relatif cepat, siklus reproduksinya singkat dengan jumlah anak rata-rata 2 ekor per kelahiran. Populasi ternak kambing di Provinsi Jawa Tengah tercatat sebanyak 4.066.654 ekor tahun 2016 dan meningkat pada tahun 2017 menjadi 4.134.034 ekor (Direktorat Jenderal Kementerian Pertanian RI, 2017). Hampir seluruh populasi ternak kambing berada di tangan petani peternak dengan sistem pemeliharaan tradisional.

Makanan utama ternak ruminansia seringkali berupa sisa tanaman pangan ditambah dengan pemberian rumput yang kualitasnya bervariasi. Tingginya derajat lignifikasi dan silika hijauan di daerah tropik akibat cepatnya perubahan komponen sel tanaman, menyebabkan pengaruh terhadap kualitas hijauan rendah yang dihasilkan (Infitria dan Khalil, 2014). Kondisi tersebut mengakibatkan nilai nutrisi (khususnya komposisi protein, mineral, vitamin) dan kecernaan hijauan pakan rendah. Pasokan nutrien yang tidak seimbang pada ruminansia dapat mengakibatkan rendahnya produktivitas (Soeparno, 2009). Peningkatan produktivitas ternak dapat dilakukan dengan menambahkan pemberian nutrien sesuai dengan potensi genetiknya (Laksana et al., 2013). Oleh karenanya, ternak yang mendapatkan pakan berkualitas rendah perlu mendapat suplemen nutrien guna meningkatkan produktivitasnya.

Pemberian multinutrien blok adalah sebagai pakan pelengkap yang diberikan bersama-sama konsentrat sebelum ternak diberi pakan hijauan/ berserat. Multinutrien blok dapat diterapkan di area ruminansia yang diberikan makan residu tanaman berserat atau ransum basal berkualitas rendah dan mengandung jumlah nutrisi terbatas (Mubi et al., 2012). Hamdan et al. (2018) menyatakan bahwa penambahan pakan penguat atau konsentrat ke dalam pakan ternak juga dapat meningkatkan palatabilitas pakan yang dikonsumsi dan pertambahan berat badan. Menurut hasil penelitian Yogyantara et al. (2014) ternak ruminansia kecil yang diberikan pakan dengan protein 19,24-19,32\% yang terdiri dari ransum konsentrat mengandung urea, kapur, dan ubi kayu dapat memperoleh bobot badan rata-rata sebesar $257,20 \mathrm{~g} / \mathrm{kg}$ PBB. Konsentrat untuk ternak Kambing Kacang umumnya disebut pakan penguat atau bahan baku pakan yang memiliki kandungan serat kasar kurang dari $18 \%$ dan mudah dicerna (Rudiah, 2011). 
Tujuan utama pemberian multinutrient block (MNB) sebagai pakan pelengkap adalah mengkatalisis pemanfaatan yang lebih efisien dari makanan berkualitas buruk. Perbaikan pemanfaatan bahan baku pakan berkualitas rendah untuk ruminansia dapat dilakukan melalui suplementasi nitrogen dan mineral yang bebas dari degradasi mikroba rumen (Dinata et al., 2015). Suplemen MNB yang biasa digunakan untuk ruminansia mengandung energi, urea, mineral penting dan vitamin, sehingga penggunaannya dapat merupakan solusi yang sangat menarik untuk mengatasi masalah kesehatan (Pujaningsih et al., 2018) dan kekurangan gizi yang dihadapi sebagian besar hewan terutama pada musim kemarau (Zarah et al., 2014). Ruminansia yang mengkonsumsi makanan berbasis hijauan perlu diberi pakan pelengkap untuk menghemat hijauan, meningkatkan kinerja hewan, dan meningkatkan keuntungan secara ekonomi (Simon, 2012).

Pemberian mineral yang cukup pada ternak diharapkan akan memberikan pengaruh yang besar pada ternak, misalnya terhadap pertambahan bobot badan, peningkatan efisiensi pakan, peningkatan ketahanan terhadap penyakit dan stress, perbaikan sistem reproduksi pada ternak sehingga ternak bisa bereproduksi sesuai potensial genetiknya, serta peningkatan karkas rendah lemak. Penelitian ini bertujuan untuk mengevaluasi pengaruh perlakuan pemberian multinutrient block dengan jumlah pemberian yang berbeda pada kambing kacang terhadap penampilan produksinya. Hasil penelitian diharapkan dapat dimanfaatkan sebagai informasi untuk pemberian multinutrient block sebagai pakan pelengkap pada ransum kambing kacang. Hipotesis yang digunakan adalah pemberian pakan pelengkap dalam bentuk MNB pada ransum basal Kambing Kacang dapat meningkatkan konsumsi bahan kering (KBK), konsumsi bahan organik (KBO) dan total digestible nutrients (TDN).

\section{METODE}

Kegiatan penelitian berlokasi di kandang kambing Desa Mrunten Kelurahan Kalisidi Kabupaten Semarang, Laboratorium Teknologi Pakan dan Laboratorium Ilmu Nutrisi Pakan pada Fakultas Peternakan dan Pertanian Universitas Diponegoro. Materi penelitian yang digunakan adalah bahan baku penyusun multinutrien blok, Kambing Kacang jantan dan bahan pakan basal. Bahan baku penyusun multinutrien blok terdiri atas hijauan jagung, urea, cangkang kerang darah, cangkang telur, molasses, bentonite dan garam. Kambing Kacang jantan yang digunakan berumur 7 bulan sebanyak 12 ekor yang dibagi menjadi 3 kelompok berdasarkan berat badannya, yaitu : K1 17,5 $\pm 2,5 \mathrm{~kg}, \mathrm{~K} 2: 15,0 \pm 2,4$ $\mathrm{kg}, \mathrm{K} 3: 13,5 \pm 1,4 \mathrm{~kg}$

Hijauan jagung dan konsentrat diberikan sebagai pakan basal dengan komposisi pemberian hijauan : konsentrat $=20: 80$. Konsentrat disusun dari bahan baku pakan berupa dedak padi, pollard, kulit kopi, molases. Formulasi pakan basal disusun berdasarkan kebutuhan nutrien ternak uji pada masing-masing kelompok (Tabel 1). Komposisi proksimat ransum perlakuan disajikan pada Tabel 2. 
Tabel 1.

Komposisi Pakan Basal Kambing Kacang ${ }^{*}$

\begin{tabular}{llll}
\hline \hline Komposisi bahan pakan & $\mathrm{K} 1$ & $\mathrm{~K} 2$ & $\mathrm{~K} 3$ \\
\cline { 2 - 4 } & $---1-0-0$ & 20.00 \\
Hijauan Jagung & 20.00 & 20.00 & 34.00 \\
Dedak padi & 18.00 & 25.00 & 40.00 \\
Pollard & 57.00 & 50.00 & 3.00 \\
Kulit Kopi & - & 2.00 & 3.00 \\
Molasses & 5.00 & 3.00 & 100 \\
\hline Total & 100 & 100 &
\end{tabular}

Keterangan : *) komposisi pakan disusun berdasarkan kebutuhan nutrien kelompok bobot badan ternak uji Kelompok BB 1 ternak uji : 17,5 $\pm 2,5 \mathrm{~kg}$,

Kelompok BB 2 ternak uji : 15,0 $\pm 2,4 \mathrm{~kg}$,

Kelompok BB 3 ternak uji :13,5 $\pm 1,4 \mathrm{~kg}$

Tabel 2.

Komposisi Proksimat Pakan dengan Multinutrien Blok sebagai

Pakan Pelengkap pada Kambing Kacang Berdasarkan Bobot Badan

Awal Ternak Uji

\begin{tabular}{lllll}
\hline \hline \multirow{2}{*}{ Kandungan Nutrien } & \multicolumn{1}{c}{ T0 } & T1 & T3 \\
\cline { 2 - 5 } & \multicolumn{4}{c}{ T2 } \\
\hline \multirow{2}{*}{ Abu } & 10.34 & 11.24 & 12.51 & 11.58 \\
Lemak Kasar & 2.01 & 1.92 & 2.2 & 1.50 \\
Protein Kasar & 9.94 & 10.34 & 11.15 & 11.02 \\
Serat Kasar & 20.89 & 21.33 & 20.08 & 22.02 \\
BETN & 56.82 & 55.18 & 54.06 & 53.87 \\
TDN* & 64.96 & 64.47 & 65.81 & 63.57 \\
\hline
\end{tabular}

Keterangan : T0 : Ransum perlakuan tanpa MNB

$\mathrm{T} 1$ : Ransum perlakuan dengan penambahan $5 \mathrm{~g}$ MNB

T2 : Ransum perlakuan dengan penambahan $10 \mathrm{~g}$ MNB

T3 : Ransum perlakuan dengan penambahan $15 \mathrm{~g}$ MNB

* ) : Perhitungan berdasarkan (Sutardi, 2001). TDN = 70,6+(0,259 x $\mathrm{PK})+(1,01 \times \mathrm{LK})-(0,760 \times \mathrm{SK})+(0,0991 \times \mathrm{BETN})$

Alat yang digunakan adalah bahan ekstrak tanpa nitrogen (BETN) chopper, grinder, paralon sebagai cetakan, masing-masing adalah 27,57\%, 21,10\%, timbangan manual, timbangan digital, $0,14 \%, 17,50 \%, 12,79 \%$ dan $42 \%$.

ember, perlengkapan analisis dan alat Penelitian dilaksanakan dalam tiga tulis. Perlengkapan analisis untuk meng- tahap. Sebelum pelaksanaan, dilakukan analisis konsumsi BK, dan BO serta tahap pendahuluan yaitu persiapan komposisi proksimat. Kandungan proksi- Kambing Kacang 12 ekor jantan dan mat multinutrien blok untuk kadar air, abu, penyiapan bahan-bahan untuk pelaksaan lemak kasar, serat kasar, protein kasar, dan penelitian yaitu kandang, pakan dan bahan 
untuk pembuatan MNB. Tahap pertama/ pendahuluan adalah adaptasi ternak selama 1 bulan yang diikuti persiapan meliputi pembuatan multinutrien blok dan adaptasi pakan pada ternak uji. Tahap kedua adalah pengambilan data dan diikuti tahap ketiga berupa analisis data.

\section{Tahap Persiapan/Pendahuluan}

Tahap persiapan penelitian dimulai dari adaptasi ternak uji, persiapan alat dan bahan yang dibutuhkan untuk penelitian serta pembuatan multinutrien blok. Adaptasi ternak uji terhadap pemberian pakan perlakuan dilakukan selama 1 bulan. Bahan-bahan penyusun multinutrien blok ditimbang merujuk pada rekomendasi formulasi Garcia dan Restrepo (1995) dan Salem dan Nefzaoui (2003) sebagai berikut: 50\% molasses, $4 \%$ urea, $7 \%$ bentonit, 3\% garam, 3\% cangkang kerang darah, 3\% cangkang telur dan 30\% hijauan jagung. Metode panas menurut Salem dan Nefzaoui (2003) digunakan untuk mencampur bahan baku penyusun multinutrien blok sampai homogen (suhu pemanasan molases pada $40-50^{\circ} \mathrm{C}$ selama 10 menit). Setelah homogen multinutrien blok dipadatkan dalam cetakan yang dibuat dari pralon kemudian diangin-anginkan selama 3 hari hingga teksturnya mengeras (gambar 1). Multinutrien blok yang sudah mengeras selanjutnya ditimbang sebanyak $5 \mathrm{~g}, 10 \mathrm{~g}$ dan $15 \mathrm{~g}$ (berat kering udara) sesuai perlakuan yang diberikan.

\section{Tahap Pelaksanaan}

Tahap pelaksanaan dilakukan setelah ternak uji beradaptasi dengan pakan perlakuan sebanyak $3,5 \%$ bobot badan ternak. Bobot badan kambing ditimbang sebanyak 5 kali dimulai pada awal perlakuan, tiap 2 minggu sekali dan pada akhir perlakuan selama 3 bulan. Pemberian pakan dilakukan pada pagi hari pukul 08.00 WIB dan sore hari pukul 15.00 WIB. Pakan konsentrat yang telah diformulasikan sesuai kebutuhan diberikan bersamaan dengan pemberian MNB sebagai pakan pelengkap. Hijauan pakan diberikan setelah 1 jam pemberian konsentrat dan diberikan secara terukur sesuai dengan kebutuhan ternak.

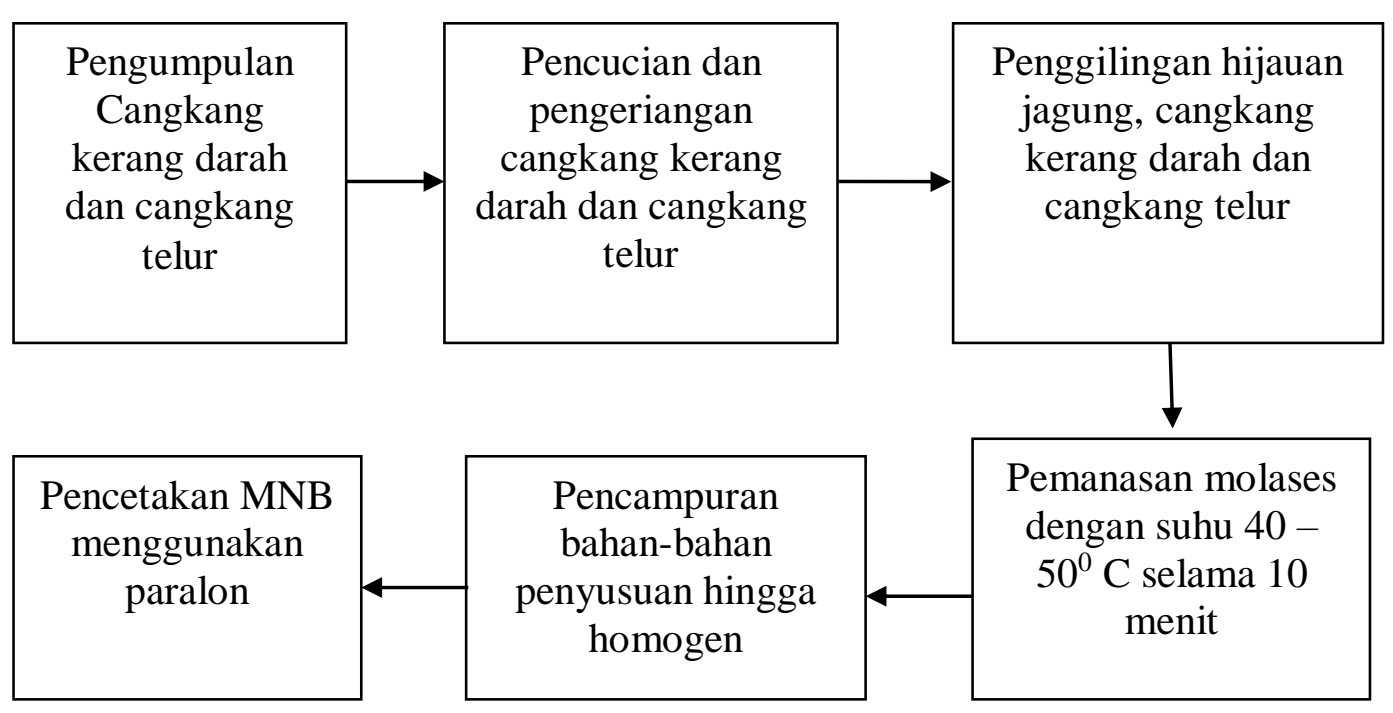

Gambar 1. Proses pembuatan MNB 


\section{Tahap Pengambilan data}

Parameter yang diamati dalam penelitian meliputi pertambahan bobot badan harian (PBBH), konsumsi bahan kering, bahan organik dan total digestible nutrients (TDN). Data yang diperoleh dihitung menggunakan rumus Haris (1970). Data hasil penelitian dianalisis dengan menggunakan Anova pada taraf 5\%. Pengaruh yang terdapat antara jumlah pemberian multinutrien blok berbeda terhadap pertambahan bobot badan harian (PBBH), konsumsi bahan kering, bahan organik dan total digestible nutrients (TDN) pada kambing kacang, diuji dengan Duncan.

\section{HASIL DAN PEMBAHASAN}

Konsumsi bahan kering

Data konsumsi bahan kering, bahan organik dan Total Digestible Nutrients kambing Kacang ditampilkan pada Tabel 3. Hasil analisis statistik menunjukkan bahwa konsumsi bahan kering tidak menunjukkan perbedaan yang nyata antar perlakuan $(\mathrm{P}>0,05)$. Hal ini menunjukkan bahwa imbangan PK dan TDN yang berbeda pada pakan perlakuan, tidak berpengaruh terhadap konsumsi BK (Tabel 4). Kondisi ini dimungkinkan karena bentuk fisik pakan perlakuan sama. Menurut Fani et al., (2016) keseragaman sifat fisik pakan dapat menyebabkan palatabilitas pakan sama.

Tabel 3.

Konsumsi Bahan Kering, Bahan Organik dan Total Digestible Nutrients Kambing Kacang

\begin{tabular}{llllc}
\hline \hline \multirow{2}{*}{ Parameter } & \multicolumn{4}{c}{ Perlakuan } \\
\cline { 2 - 5 } & T0 & T1 & T2 & T3 \\
\hline Konsumsi Bahan Kering (g/hari) & 1.066 & 936 & 952 & 895 \\
Konsumsi Bahan Organik (g/hari) & 967 & 844 & 842 & 800 \\
Konsumsi TDN (g/hari) & 693 & 603 & 629 & 570 \\
\hline
\end{tabular}

Tabel 4.

Rasio Protein Kasar dan TDN di dalam Pakan Perlakuan.

\begin{tabular}{lllll}
\hline \hline & T0 & T1 & T2 & T3 \\
\hline Protein Kasar (\%) & 9.93 & 10.06 & 11.10 & 11.15 \\
TDN (\%) & 64.96 & 65.01 & 66.00 & 64.04 \\
\hline
\end{tabular}

Konsumsi BK tertinggi secara statistik (1.066 g/ekor/hari) pada pakan perlakuan T0 diduga karena rendahnya imbangan protein dan TDN dibandingkan pakan perlakuan T2 dan T3. Dijelaskan oleh Laksana et al. (2013) bahwa umur ternak berkaitan dengan deposisi protein karena pada ternak yang masih dalam masa pertumbuhan akan membutuhkan banyak protein untuk menunjang kebutuhannya. Menurut Soeparno (2009) kambing yang telah mencapai umur 7-12 bulan pertumbuhannya mulai melambat, namun masih terus meningkat. Imbangan protein dan TDN pada ransum Kambing Kacang menurut Purbowati et al. (2015) dapat mempengaruhi kecernaan pakan, utilisasi pakan dan efisiensi pakan. Diduga karena Konsumsi pakan bukan hanya dipengaruhi oleh kandungan TDN, tetapi juga dipengaruhi oleh kadar SK. Semakin tinggi kadar SK ransum, semakin rendah 
kecernaan ransum, dan semakin rendah kecernaan ransum semakin rendah pula konsumsi BK. Akibatnya kebutuhan TDN tidak terpenuhi.

Perlakuan pakan T1 memiliki imbangan protein dan TDN yang sama dengan T0. Adanya pemberian MNB sebanyak 5 g/ekor/hari diduga mampu melengkapi ketersediaan nutrien yang diperlukan untuk metabolisme ternak uji sehingga konsumsi BK berkurang (Tabel 4). Menurut Salem dan Smith (2008) ternak yang mendapatkan mineral blok sebagai pakan pelengkap jauh lebih sehat daripada yang tidak diberi mineral blok. Raguati (2012) menyatakan bahwa pemberian mineral blok memberikan dampak positif terhadap produktifitas kambing.

Konsumsi BK yang tinggi secara statistik pada perlakuan pakan T1 dibandingkan perlakuan pakan T2 dan T3 diduga disebabkan oleh rendahnya kandungan serat kasar pada T2. Chuzaemi (2012) bahwa semakin rendah kandungan serat kasarnya menyebabkan ternak lebih cepat untuk memakan dan ruminansi dan laju degradasi dalam retikulo-rumen cepat. Kondisi ini menyebabkan ternak uji meningkatkan konsumsi BK untuk mencukupi kapasitas rumen. Konsumsi BK pada perlakuan pakan T3 paling rendah dibandingkan perlakuan pakan T1 dan T2. Keadaan ini diduga karena perlakuan pakan T3 memiliki kandungan serat kasar yang tinggi sehingga kapasitas rumen ternak uji menjadi cepat penuh. Menurut Toharmat et al., (2006) semakin tinggi kadar serat maka semakin rendah kerapatannya atau bahan tersebut semakin amba. Pakan dengan tingkat keambaan yang lebih tinggi dapat menimbulkan regangan lebih besar dan memberikan sensasi kenyang lebih cepat pada saat dikonsumsi ternak, sehingga sifat amba tersebut dapat membatasi konsumsi pada ternak.
Konsumsi bahan kering dipengaruhi juga oleh bobot badan ternak, semakin besar ukuran badan ternak semakin tinggi pula konsumsi bahan kering pakan ternak uji. Hasil penelitian Laksana et al. (2013) menyatakan bahwa bobot badan Kambing Kacang berpengaruh nyata $(\mathrm{P}<0,05)$ terhadap konsumsi BK dan konsumsi PK. Sumardianto et al. (2013) menambahkan bahwa, ukuran ternak dapat mempengaruhi jumlah pakan yang dikonsumsi. Oleh sebab itu, ukuran ternak sangat mempengaruhi kemampuannya dalam mengkonsumsi pakan.

Menurut Kearl (1982) konsumsi bahan kering untuk hidup pokok kambing dengan berat 20 sampai $25 \mathrm{~kg}$ yaitu antara 540-640 gram. Penelitian Laksana et al. (2013) menunjukkan konsumsi bahan kering antara 507 - 611 g, sehingga konsumsi bahan kering pada T0 melebihi jumlah tersebut. Rendahnya utilisasi nutrien pada pakan perlakuan T0 diduga terkait dengan kurang seimbangnya nutrien yang diserap. Keseimbangan nutrien diperoleh dari pemberian pakan pelengkap berupa multinutrien blok (Salem and Nefzaoui, 2003) yang diberikan pada T1, T2 dan T3. Peningkatan kualitas ransum dapat meningkatkan kecernaan dan retensi protein ransum pada kambing Kacang jantan (Laksana et al., 2013).

\section{Konsumsi bahan organik}

Berdasarkan analisis statistik (Tabel 3), data konsumsi bahan organik tidak menunjukkan perbedaan antar perlakuan yang nyata $(\mathrm{P}>0,05)$. Apabila tingkat konsumsi bahan kering pada ternak rendah maka diikuti tingkat konsumsi bahan organik yang rendah juga dan sebaliknya. Kondisi ini sesuai dengan Suwignyo et al., (2016) yang menyatakan bahwa konsumsi bahan organik mengikuti hasil konsumsi bahan kering karena bahan 
organik merupakan bagian dari bahan kering.

\section{Konsumsi total digestible nutrients}

Data konsumsi TDN secara statistik (Tabel 3) tidak menunjukkan perbedaan antar perlakuan yang nyata $(\mathrm{P}>0,05)$ baik pada penambahan multinutrien blok sebagai pakan pelengkap (T1,T2,T3) maupun pada pakan kontrol (T0) yang tidak diberi multinutrien blok. Diduga karena konsumsi TDN perlakuan T2 dan T3 telah mencukupi kebutuhan TDN pada Kambing Kacang, maka ternak uji menghentikan konsumsi pakannya. Pemberian $10 \mathrm{~g}$ multinutrien blok sebagai pakan pelengkap pada perlakuan T2 menghasilkan konsumsi Total Digestible Nutrient tertinggi secara deskriptif dibandingkan perlakuan T0 (tanpa MNB), T2 (MNB $10 \mathrm{~g}$ ) dan T3 (15 g). Hal ini disebabkan formulasi pakan basal T2 telah memiliki persentase TDN yang tinggi (Tabel 4) sehingga penambahan multinutrien blok dengan TDN rendah $(45,52 \%)$ tidak mengurangi persentase TDN pakan perlakuan T2.

Konsumsi TDN pada pakan perlakuan T3 menurun seiring dengan bertambahnya pemberian $15 \mathrm{~g}$ multinutrien blok. Kondisi ini dikarenakan pengurangan TDN dari formulasi pakan basal oleh penambahan persentase multinutrien blok. Pakan perlakuan T1 memiliki TDN lebih tinggi dari T3 karena TDN pada T1 tidak mengalami penurunan yang berarti seiring dengan penambahan 5 g multinutrien blok. Munawaroh et al., (2015) menyatakan bahwa konsumsi TDN dipengaruhi oleh kandungan nutrien pakan, karena TDN merupakan energi pakan yang dapat dicerna yang berasal dari kandungan nutrien pakan meliputi protein kasar, serat kasar, lemak kasar dan bahan ekstrak tanpa nitrogen. Selanjutnya dijelaskan oleh Tillman et al., (1998); Sutardi, (2001); Rama et al., (2014) dan
Munawaroh et al., (2015) bahwa kandungan nutrisi di dalam bahan pakan dipengaruhi oleh formulasi bahan baku penyusunnya.

Konsumsi TDN pada penelitian ini dipengaruhi jumlah konsumsi BK dan PK dari masing-masing perlakuan pakan serta umur ternak uji (7 bulan). Menurut Devendra dan Burns (1994), jumlah konsumsi bahan kering kambing merupakan salah satu faktor yang sangat penting karena kapasitas mengkonsumsi pakan secara aktif merupakan faktor pembatas mendasar dalam pemanfaatan pakan. Ternak akan menghentikan makannya apabila kapasitas retikulo rumennya untuk menampung massa digesta sudah mencapai batas maksimal. Ternak yang diberi perlakuan multinutrien blok mengkonsumsi BK dan PK lebih tinggi dibandingkan dengan ternak yang tidak diberi tambahan multinutrien blok, sehingga nilai konsumsi TDN menjadi tinggi. Menurut Tillman et al., (1998) ternak makan untuk memenuhi kebutuhan nutrisinya.

Hasil perhitungan konsumsi TDN pada penelitian ini lebih rendah $(569,63$ 693,14 g/ekor/hari) jika dibandingkan dengan penelitian Purbowati et al., (2015) sejumlah $762-880$ g/ekor/hari menggunakan kambing Bligon umur 1 tahun. Menurut Salem and Smith (2008) multinutrien blok mampu meningkatkan nilai gizi dari ransum berkualitas rendah seiring dengan peningkatan produksi dan kinerja reproduksi ruminansia kecil, serta mengurangi biaya penyediaan pakan.

\section{Pertambahan Bobot Badan Harian}

Hasil analisis statistik (Tabel 6) menunjukkan tidak terdapat perbedaan yang nyata antar perlakuan pakan terhadap pertambahan bobot badan harian Kambing Kacang $(\mathrm{P}>0,05)$. Hal ini diduga karena pakan basal yang diberikan sudah memiliki kandungan nutrisi yang cukup 
untuk memenuhi kebutuhan ternak uji (Tabel 5). Sehingga pemberian multinutrien blok sebagai pakan pelengkap tidak mempengaruhi bobot badan Kambing Kacang.

Menurut NRC (2007) kebutuhan protein dan TDN untuk kambing jantan dewasa yang digemukkan masing-masing adalah 38 g/ekor/hari dan 140 g/ekor/hari. Purbowati et al., (2015) menyatakan bahwa PBBH yang berbeda pada setiap individu ternak dapat diakibatkan antara lain oleh faktor pakan dan genetik.

Tabel 5.

Rata-rata Bobot Badan Kambing Kacang dengan Perlakuan Pakan yang Berbeda

\begin{tabular}{ccccc}
\hline \hline & BB Awal & BB Akhir & PBB & $\begin{array}{c}\text { Rerata } \\
\text { PBBH }\end{array}$ \\
\hline Kambing Perlakuan & $\ldots \ldots \ldots \ldots \ldots \ldots \ldots$ & $($ kg/ekor $)$ & $\ldots \ldots \ldots \ldots \ldots \ldots$. \\
K1 & 17,13 & 23,63 & 6,50 & 0,09 \\
K2 & 14,63 & 19,50 & 4,88 & 0,07 \\
K3 & 13,25 & 18,25 & 5,00 & 0,07 \\
\hline
\end{tabular}

Tabel 6.

Pertambahan Bobot Badan Harian Kambing Kacang Berdasarkan Perlakuan Pakan

\begin{tabular}{ccccc}
\hline \hline \multirow{2}{*}{ Parameter } & \multicolumn{4}{c}{ Perlakuan Pakan } \\
\cline { 2 - 5 } & T0 & T1 & T2 & T3 \\
\hline BB Awal kg/ekor & 15,8 & 15,2 & 14,8 & 14,2 \\
BB Akhir kg/ekor & 20,8 & 21,3 & 20,3 & 19,3 \\
PBB kg/ekor & 5 & 6,2 & 5,5 & 5,2 \\
Rerata PBBH kg/ekor & 0,07 & 0,08 & 0,07 & 0,06 \\
\hline
\end{tabular}

Wadhwa dan Bakshi (2014) menyatakan bahwa urea molases blok dan multinutrien blok merupakan perpaduan sempurna antara energi, protein dan mineral yang mampu meningkatkan pemanfaatan efisiensi nutrisi dalam makanan ternak yang berbasis tanaman berkualitas rendah. Berdasarkan Hartz (2016) standar kebutuhan mineral kambing untuk $\mathrm{Ca}, \mathrm{P}, \mathrm{Mg}, \mathrm{Cu}$ dan $\mathrm{Zn}$ masing-masing adalah $0,3-0,8 \% ; 0,25-$ $0,4 \% ; 0,18-0,4 \% ; 0,001-0,008 \%$ dan $0,04-$ $0,05 \%$. Standar kebutuhan mineral ini telah dipenuhi oleh kandungan mineral pakan basal (hijauan dan konsentrat) sebesar masing-masing untuk $\mathrm{Ca}, \mathrm{P}, \mathrm{Mg}$, $\mathrm{Cu}$ dan $\mathrm{Zn}$ adalah 0,712\%; 0,061\%; $0,403 \% ; \quad 0,061 \%$ dan $0,067 \%$.
Penambahan kandungan mineral MNB sejumlah $0,018 \% ; 0,145 \% ; 0,00078 \%$; $0,00020 \%$ dan $0,000018 \%$ masing-masing untuk kandungan $\mathrm{Ca}, \mathrm{P}, \mathrm{Mg}, \mathrm{Cu}$ dan $\mathrm{Zn}$ tidak memberikan pengaruh terhadap pemenuhan kebutuhan $\mathrm{Ca}$ dan $\mathrm{Mg}$ ternak uji. Bahkan untuk kandungan $\mathrm{Cu}$ dan $\mathrm{Zn}$ jumlahnya telah berlebih. Kandungan mineral $\mathrm{P}$ yang ada di dalam MNB rendah sehingga belum mampu memenuhi kekurangan mineral dalam pakan konsentrat dan hijauan yang diberikan pada kambing. Ketidakseimbangan rasio $\mathrm{Ca}: \mathrm{P}(0,712 \%: 0,061 \%)$ pakan yang diberikan pada ternak uji menyebabkan efisiensi penggunaan $\mathrm{Ca}$ tidak tercapai. Ensminger (2002) menyatakan bahwa domba (kambing) yang mendapat $\mathrm{P}$ dalam 
jumlah yang cukup dapat mentoleransi rasio $\mathrm{Ca}$ : $\mathrm{P}$ sebesar 7 : 1 dalam pakan. Efisiensi penggunaan $\mathrm{Ca}$ dari pakan dan ketersediaannya untuk ruminansia bergantung pada kecukupan tingkat $\mathrm{P}$.

Perlakuan pakan T2 dan T3 menghasilkan pertambahan bobot badan total tidak berbeda jauh dengan perlakuan pakan T0. Diduga pemberian level multinutrien blok berlebih pada T2 dan T3. Merujuk pada Widiyanto et al. (2015) nutrien yang dikeluarkan sebagai feses adalah nutrien yang tidak tecerna. Energi yang dikonsumsi ternak digunakan antara lain untuk sekresi (Salem dan Nefzaoui, 2003). Hal ini menyebabkan bobot badan akhir ternak uji (T2 dan T3) menjadi berkurang. Perlakuan pakan dengan pemberian multinutrien blok sebagai pakan pelengkap sebanyak 5 g/ekor/hari (T1) menghasilkan bobot badan akhir dan pertambahan bobot badan terbaik dibandingkan perlakuan pakan yang lain. Hal ini menunjukkan bahwa penambahan multinutrien blok pada perlakuan pakan T1 secara deskriptif mampu memperbaiki metabolisme nutrisi ternak uji meskipun secara statistik tidak berbeda nyata.

\section{SIMPULAN}

Berdasarkan hasil penelitian dapat disimpulkan bahwa pemberian multinutrien blok hingga sebanyak 15 g/ekor/hari tidak berpengaruh terhadap konsumsi bahan kering, bahan organik, total digestible nutrients dan pertambahan bobot badan kambing Kacang. Pemberian multinutrien blok sebaiknya diberikan sebagai pakan pelengkap pada ransum dengan kualitas nutrisi yang rendah untuk meningkatkan efisiensi pakan. 


\section{DAFTAR PUSTAKA}

Chuzaemi, S. 2012. Fisiologi Nutrisi Ruminansia. Universitas Brawijaya Press. Malang.

Direktorat Jendral Peternakan dan Kesehatan Hewan Kementrian Pertanian RI. 2017. Statistik Peternakan dan Kesehatan Hewan 2017. http://ditjenpkh. pertanian. go.id

Devendra, C and Burns, M. 1983. Goat Production in the Tropics. Commonwealth Agricultural Bureau. pp. 183.

Dinata, D.D, Widiyanto dan R.I. Pujaningsih. 2015. Pengaruh Suplementasi dan Proteksi Minyak Biji Kapuk Terhadap Fermentabilitas Ruminal Rumput Gajah pada Sapi Secara In Vitro. Agripet Vol 15, No. 1, April 2015

Ensminger, M.E. 2002. Sheep and Goat Science 6th Ed. Interstate Publishers Inc, Illinois.

Fani, F., R.I. Pujaningsih dan B.W.H.E. Prasetiyono. 2016. Evaluasi Partikel Hijauan pada Bebagai Ukuran dalam Ransum Segar terhadap Palatabilitas dan Kecernaan pada Kambing Lokal. Buletin Sintesis., 20(3):28-31

Garcia, L.O. and J. I. R. Restrepo. 1995. Multinutrient Block Handbook. Food and Agriculture Organization of The United Nations, Rome.

Hamdan, B.P., Purwanto, D.A., Astuti, A., Atabany, dan E. Taufik. 2018. Respon Kinerja Produksi dan Fisiologis Kambing Peranakan Ettawa terhadap Pemberian Pakan Tambahan Dedak Halus pada Agroekosistem Lahan Kering di Kalimantan Selatan. Jurnal Pengkajian dan Pengembangan Teknologi Pertanian. 21: (1):73.-84

Harris, L.E. 1970. Nutrition Research Technique for Domestic and Wild
Animal. An International Record System and Procedure for Analyzing Sample. Animal Science Department. Utah State University Logan, Utah.

Hartz. S. 2016. Introduction to Goat Nutrition. Agricultural Research and Extension Programs. Langston University. United States.

Infitria dan Khalil. 2014. Studi produksi dan kualitas hijauan di lahan padang rumput UPT peternakan Universitas Andalas Padang. Buletin Makanan Ternak. 101(1): 25-33.

Kearl, L. C. 1982. Nutrients Requirements of Ruminants in Developing Countries. Internasional Feedstuffs Institiute Utah Agricultural Experiment Station Utah State Logan University, Utah.

Laksana, A. A., E. Rianto dan M. Arifin. 2013. Pengaruh Kualitas Ransum terhadap Kecernaan dan Retensi Protein Ransum pada Kambing Kacang Jantan. J. Animal Agriculture. 2(4): 63-72.

Mubi, A. A., I. D. Mohammed and A. Kibon. 2012. Effects of Multinutrient Blocks Supplementation on the Performance of Cattle Grazing Natural Pastures in the Wet Season of Guinea Savanna Region of Nigeria. World Journal of Agricultural Sciences 8 (1): 3337.

Munawaroh, L. L., I G. S. Budisatria dan B. Suwignyo. 2015. Pengaruh pemberian fermentasi complete feed berbasis pakan lokal terhadap konsumsi, konversi pakan dan feed cost kambing bligon jantan. Buletin Peternakan. 39(3): 161173.

National Research Council. 2007. Nutrient Requirements of Small Ruminants. 
National Academy Press. Washington, DC.

Pujaningsih, R.I, Tampubolon, B.I.M.T, Widianto dan Harjanti, D.W. 2018. Evaluation of the Effectiveness of the Use of Papaya Fruit Latex in Making Herbal Medicated Multinutrition Block as a Local Goat Feed Supplement. Journal of Animal Production. 20 (20).

Purbowati, E., I. Rahmawati dan E. Rianto. 2015. Jenis hijauan pakan dan kecukupan nutrien kambing Jawarandu di kabupaten Brebes Jawa Tengah. Pastura. 5(1): 10-14.

Rama, D. F.P.A., F. Fathul dan Erwanto. 2014. Pengaruh Imbangan Hijauan Berbanding Konsentrat terhadap Kecernaan Bahan Kering, Kecernaan Bahan Organik dan Kecernaan Protein pada Kambing Pejantan di Lingkungan Panas. J. Ilmiah Peternakan Terpadu. 2(1): $29-32$.

Raguati. 2012. Suplementasi Mineral Blok Plus dalam Pakan Kambing Peranakan Ettawa terhadap Pertumbuhan dan Status Kesehatan. Agrinak. 2(1): 36-40

Retnani, Y., L. Herawati L dan S. Khusniati. 2011. Uji fisik ransum broiler stater bentuk crumble berperekat tepung tapioka, bentonit dan onggok. J Invit Theory Pract. 1:88-97.

Rudiah. 2011. Respon Kambing Kacang Jantan Terhadap Waktu Pemberian Pakan. Media Litbang Sulteng. 4(1): 67-74.

Salem, H.B and Nefzaoui, A. 2003. Feed blocks as alternative supplements for sheep and goats. Small Ruminant Research, 49(3), 275288.

Salem, H.B, and Smith, T. 2008. Feeding strategies to increase small ruminant production in dry environments. Small Ruminant Research, 77(2-3), 174-194.

Simon, P. G. 2012. Prospek penerapan teknologi proses pakan berbasis hasil samping industry perkebunan dalam ruminansia kecil. Wartazoa. 22(2): 53-64.

Sumardianto, T. A. P., E. Purbowati, dan M. Masykuri. 2013. Karakteristik Karkas Kambing Kacang, Kambing Peranakan Ettawa dan Kambing Kejobong Jantan pada Umur Satu Tahun. Animal Agriculture Journal. 2(1):175 182.

Sutardi, T. 2001. Revitalisasi peternakan sapi perah melalui penggunaan ransum berbasis limbah perkebunan dan suplementasi mineral organik. Laporan akhir RUT VIII 1. Kantor Kementrian Negara Riset dan Teknologi dan LIPI.

Suwignyo, B., U. A. Wijaya, R. Indriani, A. Kurniawati, I. Widiyono, dan Sarmin. 2016. Konsumsi, Kecernaan Nutrien, Perubahan Berat Badan dan Status Fisiologis Kambing Bligon Jantan dengan Pembatasan Pakan. Jurnal Sains Veteriner. 34(2): 210-219.

Soeparno. 2009. Ilmu dan Teknologi Daging. Cetakan V. Gadjah Mada University Press. Yogyakarta.

Tillman, A. D., H. Hartadi, S. Reksohadiprodjo, S. Prawiro Kusuma dan S. Lebdosoekoekojo. 1998. Ilmu Makanan Ternak Dasar. Gadjah Mada University Press, Yogyakarta.

Toharmat, T., E. Nursasih, R. Nazilah, N. Hotimah, T. Q. Noerzihad, N.A. Sigit dan Y. Retnani. 2006. Sifat Fisik Pakan Kaya Serat dan Pengaruhnya terhadap Konsumsi dan Kecernaan Nutrien Ransum 
pada Kambing. Media Peternakan, 29 (3):146-154

Zarah, A. I., I. D. Mohammed dan F. I. Abbator. 2014. Rumen degradation characteristic of multinutrient blocks in Semi-Arid region of Nigeria. J. Animal Production. 16 (1) : 25-30.

Wadhwa, M and M.P.S. Bakshi. 2014. Nutritional evaluation of urea molasses multi-nutrient blocks containing agro-industrial wastes in buffaloes. Indian Journal of Animal Sciences 84 (5): 544-548.

Widiyanto, E. Pangestu, Surahmanto, V.D. Yunianto, B.I.M. Tampoebolon and B.W.H.E. Prasetiyono. 2015. Effect of Mineral Supplementation and Introduction of Setaria sphacelata Grass and Gliricidia sepium Legume on Productivity of Kacang Goat at Serang River Basin Upland Area, Central Java, Indonesia. Pakistan Journal of Nutrition. Volume: 14(8):440-446.

Yogyantara, A.P. I. K.D. I. W. Suarna dan N. N. Suryani. 2014. Pengaruh level konsentrat dalam ransum terhadap komposisi tubuh kambing. Peranakan etawah. Majalah Ilmiah Peternakan. 17(3): 113-116. 